\title{
Arthrobacter livingstonensis sp. nov. and Arthrobacter cryotolerans sp. nov., salt-tolerant and psychrotolerant species from Antarctic soil
}

\author{
Lars Ganzert, ${ }^{1}$ Felizitas Bajerski, ${ }^{1}$ Kai Mangelsdorf, ${ }^{2}$ André Lipski ${ }^{3}$ \\ and Dirk Wagner ${ }^{1}$
}

Correspondence

Lars Ganzert

Lars.Ganzert@awi.de

\author{
${ }^{1}$ Alfred Wegener Institute for Polar and Marine Research, Research Department Potsdam, \\ Telegrafenberg A45, 14473 Potsdam, Germany \\ ${ }^{2}$ Helmholtz Centre Potsdam GFZ German Research Centre for Geosciences, Section 4.3, Organic \\ Geochemistry, Telegrafenberg B 423, 14473 Potsdam, Germany \\ ${ }^{3}$ Rheinische Friedrich-Wilhelms-Universität Bonn, Institute of Nutrition and Food Sciences, \\ Department of Food Microbiology and Hygiene, Meckenheimer Allee 168, 53115 Bonn, Germany
}

Two novel cold-tolerant, Gram-stain-positive, motile, facultatively anaerobic bacterial strains, LI2 ${ }^{\top}$ and $\mathrm{LI}^{\top}{ }^{\top}$, were isolated from moss-covered soil from Livingston Island, Antarctica, near the Bulgarian station St Kliment Ohridski. A rod-coccus cycle was observed for both strains. 16S rRNA gene sequence analysis revealed an affiliation to the genus Arthrobacter, with the highest similarity to Arthrobacter stackebrandtii and Arthrobacter psychrochitiniphilus for strain $\mathrm{LI} 2^{\top}$ (97.8 and $97.7 \%$ similarity to the respective type strains) and to Arthrobacter kerguelensis and Arthrobacter psychrophenolicus for strain $\mathrm{LI}^{\top}$ (97.4 and $97.3 \%$ similarity to the respective type strains). The growth temperature range was -6 to $28{ }^{\circ} \mathrm{C}$ for $\mathrm{LI} 2^{\top}$ and -6 to $24{ }^{\circ} \mathrm{C}$ for $\mathrm{LI} 3^{\top}$, with an optimum at $16{ }^{\circ} \mathrm{C}$ for both strains. Growth occurred at $0-10 \%(w / v) ~ N a C l$, with optimum growth at $0-1 \%(\mathrm{w} / \mathrm{v})$ for $\mathrm{LI} 2^{\top}$ and $0.5-3 \%(\mathrm{w} / \mathrm{v})$ for $\mathrm{LI} 3^{\top}$. The $\mathrm{pH}$ range for growth was $\mathrm{pH}$ 4-9.5 with an optimum of $\mathrm{pH} 8$ for $\mathrm{LI}^{\top}$ and $\mathrm{pH} 6.5$ for $\mathrm{LI}^{\top}{ }^{\top}$. The predominant fatty acids were anteiso- $C_{15: 0}, C_{18: 0}$ and anteiso- $C_{17: 0}$ for $L I 2^{\top}$ and anteiso- $C_{15: 0}$ and $C_{18: 0}$ for $L I^{\top}{ }^{\top}$. Physiological and biochemical tests clearly differentiated strain $\mathrm{LI} 2^{\top}$ from $A$. stackebrandtii and $A$. psychrochitiniphilus and strain $\mathrm{LI}^{\top}{ }^{\top}$ from $A$. kerguelensis and $A$. psychrophenolicus. Therefore, two novel species within the genus Arthrobacter are proposed: Arthrobacter livingstonensis sp. nov. (type strain $\mathrm{LI} 2^{\top}=\mathrm{DSM} 22825^{\top}=\mathrm{NCCB} 100314^{\top}$ ) and Arthrobacter cryotolerans sp. nov. (type strain $\mathrm{LI}^{\top}=\mathrm{DSM} 22826^{\top}=\mathrm{NCCB} 100315^{\top}$ ).
Species of the genus Arthrobacter, proposed by Conn \& Dimmick (1947), have been isolated from very different sources, such as human specimens (Funke et al., 1998; Hou et al., 1998; Wauters et al., 2000; Mages et al., 2008), filtration substrates (Ding et al., 2009), the surfaces of cheese (Irlinger et al., 2005), soil and sediment (Phillips, 1953; Lee et al., 2003; Kageyama et al., 2008) as well as sewage and wastewater reservoir sediment (Kim et al., 2008; Roh et al., 2008). Some isolates are able to degrade complex organic compounds (Kodama et al., 1992; Westerberg et al., 2000; Kotoučková et al., 2004; Kallimanis et al., 2009). Over the last decade, several novel species belonging to the genus Arthrobacter have been isolated from cold environments such as an alpine ice cave (Margesin et al., 2004), an alpine soil (Zhang et al., 2010) and various terrestrial and aquatic habitats in the Antarctic

The GenBank/EMBL/DDBJ accession numbers for the 16S rRNA gene sequences of strains $L I 2^{\top}$ and $L I 3^{\top}$ are GQ406811 and GQ406812.
(Reddy et al., 2000, 2002; Gupta et al., 2004; Chen et al., 2005; Wang et al., 2009).

In this study, we describe the characterization of two strains from a cold terrestrial environment in the maritime Antarctic and propose to classify them within two novel species of the genus Arthrobacter.

Strains $\mathrm{LI} 2^{\mathrm{T}}$ and $\mathrm{LI} 3^{\mathrm{T}}$ were isolated from a moss-layered soil sample collected in 2005 near the Bulgarian Antarctic station St Kliment Ohridski ( $62^{\circ} 38^{\prime} 29^{\prime \prime}$ S $60^{\circ} 21^{\prime} 53^{\prime \prime} \mathrm{W}$ ), located on Livingston Island in the South Shetland archipelago. The soil was stored at $-20{ }^{\circ} \mathrm{C}$ for further microbiological investigations. For isolation, $5 \mathrm{~g}$ soil was mixed with $10 \mathrm{ml}$ sterile $0.9 \%(\mathrm{w} / \mathrm{v}) \mathrm{NaCl}$ and shaken at $4{ }^{\circ} \mathrm{C}$ for $20 \mathrm{~min}$ at 150 r.p.m. Serial dilutions were made with sterile saline solution $(0.9 \%, \mathrm{w} / \mathrm{v}, \mathrm{NaCl})$, plated $(0.1 \mathrm{ml})$ on a modified, synthetic BRII agar (Bunt \& Rovira, 1955) and incubated at $16{ }^{\circ} \mathrm{C}$ for 7-14 days. Single colonies were then chosen for further purification. The medium used for isolation 
contained (w/v unless indicated) $0.04 \% \mathrm{~K}_{2} \mathrm{HPO}_{4} \cdot 3 \mathrm{H}_{2} \mathrm{O}$, $0.05 \% \quad\left(\mathrm{NH}_{4}\right)_{2} \mathrm{HPO}_{4}, \quad 0.0005 \% \quad \mathrm{MgSO}_{4} .7 \mathrm{H}_{2} \mathrm{O}, \quad 0.01 \%$ $\mathrm{MgCl}_{2} \cdot 6 \mathrm{H}_{2} \mathrm{O}, 0.0001 \% \mathrm{FeCl}_{3} \cdot 6 \mathrm{H}_{2} \mathrm{O}, 0.01 \% \mathrm{CaCl}_{2} \cdot 2 \mathrm{H}_{2} \mathrm{O}$, $0.1 \%$ tryptone, $0.1 \%$ yeast extract, $0.5 \%$ glucose, $0.03 \%$ $\mathrm{Na}_{2} \mathrm{CO}_{3}, 25 \%(\mathrm{v} / \mathrm{v})$ synthetic stone extract and $1.5 \%$ agar, $\mathrm{pH}$ 8.0. The synthetic stone extract consisted of $41.5 \mathrm{mg}$ $\mathrm{NaCl}, 12.5 \mathrm{mg} \quad \mathrm{AlCl}_{3} .6 \mathrm{H}_{2} \mathrm{O}, 5.0 \mathrm{mg} \mathrm{KNO}_{3}, 80.0 \mathrm{mg}$ $\mathrm{K}_{2} \mathrm{SO}_{4}, 67.0 \mathrm{mg} \mathrm{CaSO}_{4} \cdot 2 \mathrm{H}_{2} \mathrm{O}, 54.0 \mathrm{mg} \mathrm{MgSO}_{4} .7 \mathrm{H}_{2} \mathrm{O}$ and $1 \mathrm{ml}$ trace metal mixture in $1000 \mathrm{ml}$ deionized water, $\mathrm{pH}$ 7.0. The trace metal mixture contained $2.86 \mathrm{~g} \mathrm{H}_{3} \mathrm{BO}_{3}$, $1.81 \mathrm{~g} \quad \mathrm{MnCl}_{2} .4 \mathrm{H}_{2} \mathrm{O}, \quad 0.22 \mathrm{~g} \quad \mathrm{ZnSO}_{4} .7 \mathrm{H}_{2} \mathrm{O}, \quad 0.39 \mathrm{~g}$ $\mathrm{Na}_{2} \mathrm{MoO}_{4} \cdot 2 \mathrm{H}_{2} \mathrm{O}, 0.079 \mathrm{~g} \quad \mathrm{CuSO}_{4} \cdot 5 \mathrm{H}_{2} \mathrm{O}$ and $0.049 \mathrm{~g}$ $\mathrm{Co}\left(\mathrm{NO}_{3}\right)_{2} \cdot 6 \mathrm{H}_{2} \mathrm{O}$ in $1000 \mathrm{ml}$ deionized water. For maintenance and for determination of morphological, biochemical and physiological characteristics, the isolates were grown at $16{ }^{\circ} \mathrm{C}$ on half-strength $\mathrm{LB}$ medium (w/v; $0.5 \%$ tryptone, $0.25 \%$ yeast extract, $0.5 \% \mathrm{NaCl}$ and, if necessary, $1.5 \%$ agar, $\mathrm{pH} 7.2$ ). Growth was tested at temperatures from -6 to $28{ }^{\circ} \mathrm{C}$ for strain $\mathrm{LI}^{\mathrm{T}}$ and up to $32{ }^{\circ} \mathrm{C}$ for strain $\mathrm{LI} 2^{\mathrm{T}}$ by measuring the $\mathrm{OD}_{600}$ over 5 7 days. Salt $(\mathrm{NaCl})$ tolerance was tested from 0 to $10 \%$ (w/v) over 5-7 days. $\mathrm{pH}$ tolerance and optimum $\mathrm{pH}$ for growth were evaluated from $\mathrm{pH} 4$ to 10 (in increments of $0.5 \mathrm{pH}$ units) over 5-7 days. Anaerobic growth was tested on PYG agar plates (w/v; $0.1 \%$ peptone, $0.1 \%$ yeast extract, $0.2 \%$ glucose, $1.5 \%$ agar, $\mathrm{pH} 7.2)$ incubated under a $\mathrm{N}_{2} / \mathrm{CO}_{2}(80: 20, \mathrm{v} / \mathrm{v})$ atmosphere for 14 days. Colony characteristics were determined visually on agar plates after between 7 and 14 days of bacterial growth. Cell morphology was examined by light microscopy of cells grown for 2 and 9 days. Gram staining and flagellum and spore detection were carried out by classical procedures described by Süssmuth et al. (1999). Susceptibility to antibiotics and lysozyme was examined by a filter disc test ( $10 \mu \mathrm{g}$ per disc). Acid production from carbohydrates was tested with peptone water $(\mathrm{w} / \mathrm{v} ; 1 \%$ peptone, $0.5 \% \mathrm{NaCl}$ ) containing solutions of various sugars $(1 \%, \mathrm{w} / \mathrm{v})$ and bromothymol blue as an indicator according to Hugh \& Leifson (1953). The methyl red test was performed according to Schröder (1991). Catalase activity was determined by bubble production in a $10 \%$ hydrogen peroxide solution. Oxidase activity was analysed with $N, N, N^{\prime}, N^{\prime}$-tetramethyl-p-phenylenediamine (TMPD) as a redox indicator as described by Kovács (1956). Hydrolysis of starch and casein and the production of urease, hydrogen sulfide and indole from tryptophan were determined as described by Schröder (1991). Hydrolysis of gelatin was tested by flooding gelatin agar plates with saturated ammonium sulfate solution after incubation. To test the utilization of carbon compounds as sole carbon sources, a minimal medium was prepared $[\mathrm{w} / \mathrm{v}$ unless indicated; $0.1 \% \mathrm{NH}_{4} \mathrm{Cl}, 0.1 \% \mathrm{~K}_{2} \mathrm{HPO}_{4}, 0.05 \% \mathrm{KH}_{2} \mathrm{PO}_{4}$, $0.02 \% \mathrm{MgSO}_{4} .7 \mathrm{H}_{2} \mathrm{O}, 0.005 \% \mathrm{CaCl}_{2} .2 \mathrm{H}_{2} \mathrm{O}, 0.2 \%(\mathrm{v} / \mathrm{v})$ trace metal mixture, $1.5 \%$ agar] with $0.25 \%(\mathrm{w} / \mathrm{v})$ of each carbon compound.

For quantitative analysis of cellular fatty acid compositions, cells were grown in half-strength LB medium ( $\mathrm{pH}$ 7.2) at
$16{ }^{\circ} \mathrm{C}$ for 3 days. Extraction and analysis of polar lipids and fatty acid methyl esters was conducted according to Zink \& Mangelsdorf (2004). Isoprenoid quinones were extracted using the small-scale integrated procedure of Minnikin et al. (1984). Menaquinones were analysed with a Hewlett Packard series 1050 HPLC equipped with an ODS Hypersil column and a diode-array detector. Methanol/isopropyl ether $(9: 2, \mathrm{v} / \mathrm{v})$ was used as the mobile phase at a flow rate of $1.0 \mathrm{ml} \mathrm{min}{ }^{-1}$ and a column temperature of $30{ }^{\circ} \mathrm{C}(\mathrm{Hu}$ et al., 1999). To determine the peptidoglycan structure, cell-wall extracts were prepared according to the method of Schleifer \& Kandler (1972). After derivatization (MacKenzie, 1987), the molar ratio of the amino acids was determined by GC (Groth et al., 1996). Identified fatty acids were anteiso- $\mathrm{C}_{15: 0}(36.4 \%), \mathrm{C}_{18: 0}(23.0 \%)$, anteiso$\mathrm{C}_{17: 0}(22.1 \%), \mathrm{C}_{16: 0}(10.5 \%)$, iso- $\mathrm{C}_{17: 0}(2.3 \%)$, iso- $\mathrm{C}_{15: 0}$ $(2.0 \%)$, iso- $\mathrm{C}_{16: 0}(1.5 \%), \mathrm{C}_{18: 1} \omega 9 c(1.5 \%)$ and $\mathrm{C}_{14: 0}$ $(0.7 \%)$ for LI $^{\mathrm{T}}$ and anteiso- $\mathrm{C}_{15: 0}(40.1 \%), \mathrm{C}_{18: 0}$ $(23.8 \%), \mathrm{C}_{16: 0}(10.8 \%), \mathrm{C}_{18: 2}(7.9 \%), \mathrm{C}_{18: 1} \omega 9 c(5.8 \%)$, iso- $\mathrm{C}_{15: 0}(4.1 \%)$, anteiso- $\mathrm{C}_{17: 1} \omega 8(2.9 \%)$, anteiso- $\mathrm{C}_{17: 0}$ $(1.8 \%), \mathrm{C}_{20: 0}(1.1 \%), \mathrm{C}_{18: 1} \omega 7 c(0.6 \%), \mathrm{C}_{14: 0}(0.5 \%)$, iso- $\mathrm{C}_{16: 0}(0.4 \%)$ and $\mathrm{C}_{17: 0}(0.3 \%)$ for $\mathrm{LI}^{\mathrm{T}}$. The polar lipids were characterized by the presence of phosphatidylglycerol only. Identified menaquinones were MK-9 $\left(\mathrm{H}_{2}\right)$ (69\%), MK-7 $\left(\mathrm{H}_{2}\right)(22 \%)$ and MK- $8\left(\mathrm{H}_{2}\right)(9 \%)$ for strain LI2 ${ }^{\mathrm{T}}$ and MK-9 (47\%), MK-10 (20\%), MK-8 (17\%), MK$7(12 \%)$ and MK-6 (4\%) for strain $\mathrm{LI}^{\mathrm{T}}$. For strain $\mathrm{LI}^{\mathrm{T}}{ }^{\mathrm{T}}$, peptidoglycan structure analyses revealed type A $3 \alpha$ with a Lys-Thr-Ala interpeptide bridge and a substitution of the $\alpha$-carboxyl group of D-glutamic acid by alanine amide, type A11.26 (DSMZ, 2001). Amino acid analyses of cell walls showed the presence of alanine, threonine and glutamic acid, with lysine as the diagnostic diamino acid. The molar ratio of Ala/Glu/Thr/Lys was $3.9: 1.0: 0.6: 0.6$. For strain $\mathrm{LI}^{\mathrm{T}}$, the cell-wall peptidoglycan was characterized by the presence of glutamic acid, alanine and lysine as the diagnostic diamino acid, at a molar ratio of $1.7: 1.2: 1.0$. The peptidoglycan type was A4 $\alpha$ with a Lys-Glu interpeptide bridge, with glutamic acid at the $\mathrm{N}$ terminus (after Schleifer, 1985), type A11.54 (DSMZ, 2001).

Isolation of DNA from strains $\mathrm{LI}^{\mathrm{T}}$ and $\mathrm{LI}^{\mathrm{T}}$ was done using a Microbial DNA isolation kit (MoBio Laboratories) according to the manufacturer's protocol. For 16S rRNA gene amplification, general bacterial primers $8 \mathrm{~F}$ (Ravenschlag et al., 1999) and 1492R (Dojka et al., 1998) were used. Sequencing (by GATC Biotech, Konstanz, Germany) resulted in a $1379 \mathrm{bp}$ gene product for $\mathrm{LI}^{\mathrm{T}}$ and a $1364 \mathrm{bp}$ gene product for $\mathrm{LI}^{\mathrm{T}}$. Alignments were done with closely related sequences obtained from GenBank using the integrated sINA alignment tool from the ARB-SILVA website (Pruesse et al., 2007) and were checked manually. The ARB program (Ludwig et al., 2004) was used for calculation of evolutionary distances and to construct a phylogenetic tree by the neighbour-joining method (Saitou \& Nei, 1987; Fig. 1) using the correction of Jukes \& Cantor (1969) and a termini filter that is implemented in the ARB program. To evaluate the tree 
topologies, a bootstrap analysis with 1000 replications was performed. For strain $\mathrm{LI} 2^{\mathrm{T}}$, highest $16 \mathrm{~S}$ rRNA gene sequence similarity was found to the type strains of Arthrobacter stackebrandtii (97.8\%) and Arthrobacter psychrochitiniphilus (97.7\%), whereas strain $\mathrm{LI}^{\mathrm{T}}$ showed the highest sequence similarity to the type strains of Arthrobacter kerguelensis (97.4\%) and Arthrobacter psychrophenolicus (97.3\%). 16S rRNA gene sequence similarity between $\mathrm{LI}^{\mathrm{T}}$ and $\mathrm{LI}^{\mathrm{T}}$ was only $95.5 \%$. As the $16 \mathrm{~S}$ rRNA gene sequence similarity between the two novel strains was well below the value of $98.5 \%$ defined by Stackebrandt \& Ebers (2006) as the threshold for requiring DNA-DNA hybridization experiments, we did not carry out this analysis. Determination of $\mathrm{G}+\mathrm{C}$ content of DNA was done by HPLC according to the method of Mesbah et al. (1989).

Based on differences in their morphological, physiological and biochemical characteristics, strains $\mathrm{LI} 2^{\mathrm{T}}$ and $\mathrm{LI} 3^{\mathrm{T}}$ can

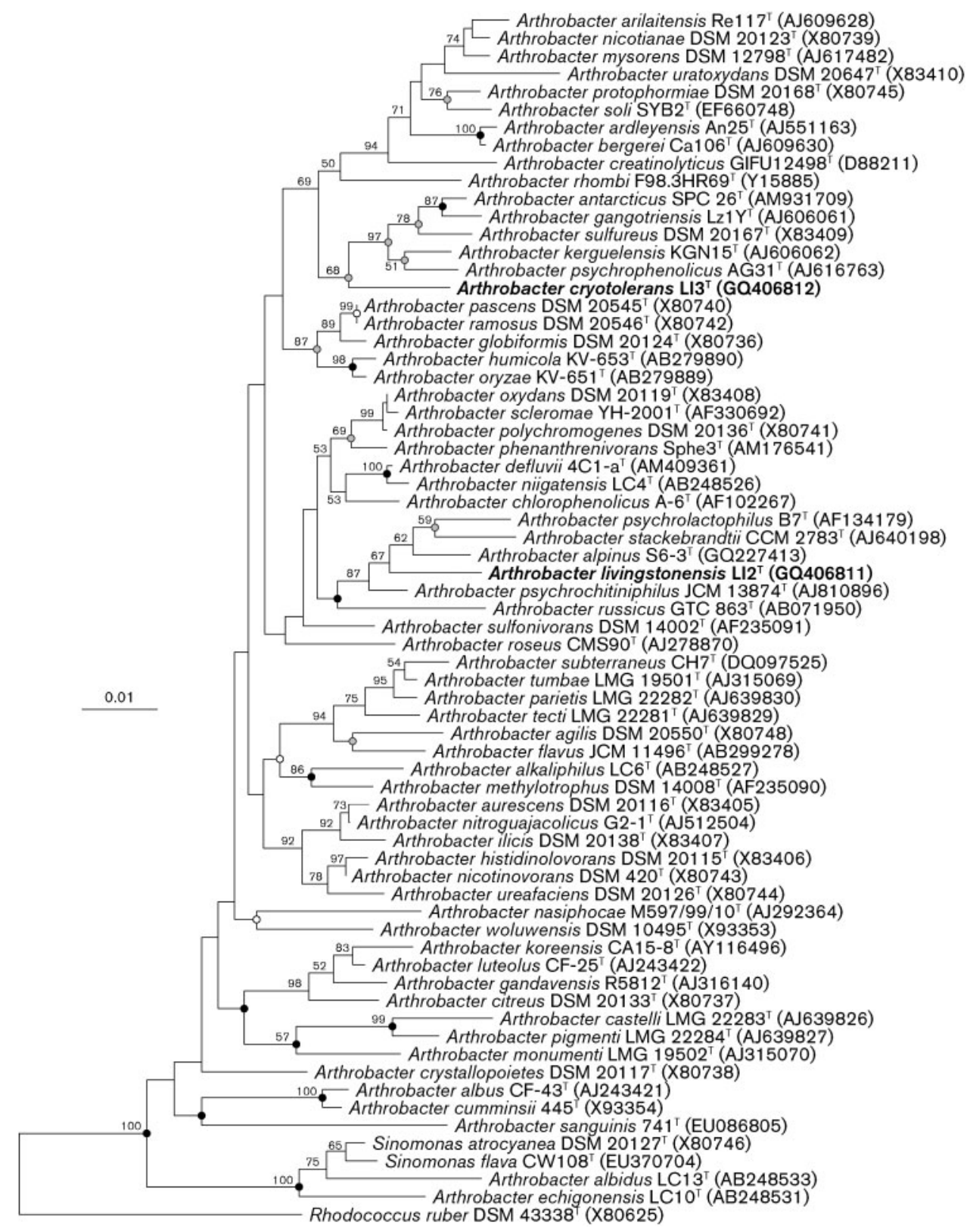

Fig. 1. Neighbour-joining tree based on 16S rRNA gene sequences showing the phylogenetic positions of $\operatorname{strains} \mathrm{LI} 2^{\top}$ and $L I 3^{\top}$ within the genus Arthrobacter. Open circles indicate branches that were also found in maximum-parsimony trees (Fitch, 1971) and shaded circles indicate branches that were also found in maximum-likelihood trees (Felsenstein, 1981); filled circles indicate branches found in both. Numbers at nodes indicate bootstrap percentages (Felsenstein, 1985) based on a neighbourjoining analysis of 1000 replications; only values $\geqslant 50 \%$ are shown. Bar, 0.01 substitutions per nucleotide position. 
be differentiated from the most closely related neighbours within the genus Arthrobacter (Table 1). We therefore propose the novel species Arthrobacter livingstonensis sp. nov. and Arthrobacter cryotolerans sp. nov., respectively, to accommodate the two strains.

\section{Description of Arthrobacter livingstonensis sp. nov.}

Arthrobacter livingstonensis (li.ving.sto.nen'sis. N.L. masc. adj. livingstonensis pertaining to Livingston Island, Antarctica, the sampling location of the soil from which the type strain was isolated).

Colonies are off-white, opaque, round, slightly convex and glossy with entire margins. Cells are facultatively anaerobic, psychrotolerant, Gram-stain-positive, motile, non-sporeforming and exhibit a rod-coccus cycle. Growth occurs from -6 to $28{ }^{\circ} \mathrm{C}$, at $\mathrm{pH} 4.0-9.5$ and in the presence of 0 $10 \%(\mathrm{w} / \mathrm{v}) \mathrm{NaCl}$, with optimum growth at $16{ }^{\circ} \mathrm{C}, \mathrm{pH} 8.0$ and $0-1 \%(\mathrm{w} / \mathrm{v}) \mathrm{NaCl}$. Positive for catalase, $\mathrm{H}_{2} \mathrm{~S}$ production and urease and negative for oxidase, indole production and the methyl red test. Does not hydrolyse starch. Casein hydrolysis is weak. Acid is produced from D-glucose and D-mannitol and is produced weakly from D-galactose and sucrose. No acid is produced from adonitol, Larabinose, L-arabitol, cellobiose, dulcitol, meso-erythritol, D-fructose, L-fucose, inulin, lactose, maltose, D-mannose, melibiose, melezitose, raffinose, L-rhamnose, D-ribose, salicin, D-sorbitol, trehalose or D-xylose. Can utilize

Table 1. Phenotypic characteristics that differentiate isolates $\mathrm{LI} 2^{\top}$ and $\mathrm{LI} 3^{\top}$ from the type strains of related Arthrobacter species

Strains: 1, Arthrobacter livingstonensis sp. nov. LI2 ${ }^{\mathrm{T}} ; 2$, Arthrobacter cryotolerans sp. nov. LI ${ }^{\mathrm{T}} ; 3$, A. psychrochitiniphilus JCM $13874^{\mathrm{T}}$ (data from Wang et al., 2009); 4, A. stackebrandtii DSM 16005 ${ }^{\mathrm{T}}$ (Tvrzová et al., 2005); 5, A. psychrophenolicus DSM 15454 ${ }^{\mathrm{T}}$ (Margesin et al., 2004); 6, A. alpinus S6-3 $3^{\mathrm{T}}$ (Zhang et al., 2010); 7, A. kerguelensis DSM $15797^{\mathrm{T}}$ (Gupta et al., 2004). +, Positive; -, negative; w, weakly positive; ND, no data available.

\begin{tabular}{|c|c|c|c|c|c|c|c|}
\hline Characteristic & 1 & 2 & 3 & 4 & 5 & 6 & 7 \\
\hline Colony colour & Off-white & Yellow & Yellow & ND & Yellow & Yellow & Yellow \\
\hline Motility & + & + & + & - & - & - & - \\
\hline \multicolumn{8}{|l|}{$\begin{array}{l}\text { Growth temperature } \\
\left({ }^{\circ} \mathrm{C}\right)\end{array}$} \\
\hline Range & -6 to 28 & -6 to 24 & $0-25$ & $4-30$ & $1-25$ & $1-25$ & $4-30$ \\
\hline Optimum & 16 & 16 & 20 & $\mathrm{ND}$ & 25 & $20-25$ & 22 \\
\hline \multicolumn{8}{|l|}{$\mathrm{pH}$ for growth } \\
\hline Range & $4-9.5$ & $4-9.5$ & ND & $5.7-9.1$ & $6-10$ & $6-9$ & ND \\
\hline Optimum & 8 & 6.5 & $6-8$ & $\mathrm{ND}$ & $\mathrm{ND}$ & ND & 7 \\
\hline $\begin{array}{l}\mathrm{NaCl} \text { growth range (\%, } \\
\text { w/v) }\end{array}$ & $0-10$ & $0-10$ & $0-3$ & $\leqslant 5$ & $1-5$ & $0-5$ & $\leqslant 6$ \\
\hline Obligately aerobic & - & - & + & + & + & + & ND \\
\hline \multicolumn{8}{|l|}{ Hydrolysis of: } \\
\hline Gelatin & - & - & - & + & - & ND & + \\
\hline Casein & $\mathrm{W}$ & - & ND & ND & ND & - & + \\
\hline Urea & + & - & - & + & + & + & + \\
\hline Starch & - & - & + & + & ND & + & - \\
\hline $\mathrm{H}_{2} \mathrm{~S}$ production & + & + & - & $\mathrm{ND}$ & - & - & $\mathrm{ND}$ \\
\hline \multicolumn{8}{|l|}{ Utilization of: } \\
\hline D-Glucose & + & + & + & + & - & + & + \\
\hline Glycerol & + & - & + & + & + & ND & - \\
\hline L-Fucose & + & - & - & + & ND & ND & ND \\
\hline Sucrose & + & - & + & + & ND & ND & + \\
\hline Inulin & + & - & - & - & ND & $\mathrm{ND}$ & + \\
\hline Glycogen & + & + & - & - & ND & ND & ND \\
\hline Lactose & + & - & + & + & $\mathrm{ND}$ & + & + \\
\hline D-Mannose & + & $\mathrm{w}$ & + & + & - & + & + \\
\hline Melezitose & + & $\mathrm{W}$ & + & - & ND & $\mathrm{ND}$ & $\mathrm{ND}$ \\
\hline D-Xylose & + & - & + & + & ND & ND & + \\
\hline Peptidoglycan type & A $3 \alpha$ Lys-Thr-Ala & A $4 \alpha$ Lys-Glu & $\mathrm{A} 3 \alpha$ & $\mathrm{A} 3 \alpha \mathrm{Thr}-\mathrm{Ala}_{3}$ & A $4 \alpha$ Lys-Glu & $\begin{array}{c}\text { A3 } \alpha \text { Lys-Thr- } \\
\mathrm{Ala}_{3}\end{array}$ & A $4 \alpha$ Lys-Glu \\
\hline Menaquinone(s) & $\begin{array}{c}9\left(\mathrm{H}_{2}\right), 7\left(\mathrm{H}_{2}\right) \\
8\left(\mathrm{H}_{2}\right)\end{array}$ & $9,10,8,7,6$ & $9\left(\mathrm{H}_{2}\right)$ & $\begin{array}{c}9\left(\mathrm{H}_{2}\right), 10\left(\mathrm{H}_{2}\right) \\
11\left(\mathrm{H}_{2}\right)\end{array}$ & $10,9,11$ & $\begin{array}{c}9\left(\mathrm{H}_{2}\right), 8\left(\mathrm{H}_{2}\right) \\
10\left(\mathrm{H}_{2}\right)\end{array}$ & $9,8,10$ \\
\hline $\begin{array}{l}\text { DNA G }+\mathrm{C} \text { content } \\
(\mathrm{mol} \%)\end{array}$ & 64.7 & 64.5 & 58.5 & $\mathrm{ND}$ & $\mathrm{ND}$ & 61.9 & 58 \\
\hline
\end{tabular}


L-arabitol, cellobiose, dulcitol, D-fructose, L-fucose, Dglucose, inulin, lactose, maltose, D-mannose, melibiose, melezitose, raffinose, D-ribose, D-salicin, sorbitol, sucrose, trehalose, D-xylose, glycerol, glycogen, L-asparagine, glycine, acetate, pyruvate and succinate as sole carbon sources, but not adonitol, meso-erythritol, formate, lactic acid or Lrhamnose. Sensitive to (10 $\mu \mathrm{g}$ per disc) penicillin, ampicillin, kanamycin, neomycin, streptomycin, erythromycin, oxytetracycline, novobiocin and rifampicin. Major fatty acids $\left(>20 \%\right.$ of total fatty acids) are anteiso- $\mathrm{C}_{15: 0}$, anteiso- $\mathrm{C}_{17: 0}$ and $\mathrm{C}_{18: 0}$. The major menaquinone is MK$9\left(\mathrm{H}_{2}\right)$. The $\mathrm{G}+\mathrm{C}$ content of the genomic DNA of the type strain is $64.7 \mathrm{~mol} \%$.

The type strain is $\mathrm{LI} 2^{\mathrm{T}}\left(=\right.$ DSM $22825^{\mathrm{T}}=$ NCCB $\left.100314^{\mathrm{T}}\right)$, isolated from a moss-covered soil from Livingston Island, South Shetland Islands, Antarctica.

\section{Description of Arthrobacter cryotolerans sp. nov.}

Arthrobacter cryotolerans (cry.o.to'ler.ans. N.L. cryo from Gr. adj. krýos cold; L. pres. part. tolerans tolerating, enduring; N.L. part. adj. cryotolerans cold-tolerating).

Colonies are yellow, opaque, round, convex and glossy with a slimy consistency and entire margins. Cells are facultatively anaerobic, psychrotolerant, Gram-stain-positive, motile, non-spore-forming and exhibit a rod-coccus cycle. Growth occurs from -6 to $24{ }^{\circ} \mathrm{C}$, at $\mathrm{pH} 4.0-9.5$ and in the presence of $0-10 \%(\mathrm{w} / \mathrm{v}) \mathrm{NaCl}$, with optimum growth at $16{ }^{\circ} \mathrm{C}, \mathrm{pH} 6.5$ and $0.5-3.0 \%(\mathrm{w} / \mathrm{v}) \mathrm{NaCl}$. Positive for catalase and $\mathrm{H}_{2} \mathrm{~S}$ production, and negative for oxidase, urease, indole production and the methyl red test. Does not hydrolyse starch or casein. Acid is produced weakly from D-fructose and L-rhamnose. No acid is produced from adonitol, L-arabinose, L-arabitol, cellobiose, dulcitol, meso-erythritol, L-fucose, D-glucose, Dgalactose, inulin, lactose, maltose, D-mannose, D-mannitol, melibiose, melezitose, raffinose, D-ribose, salicin, Dsorbitol, sucrose, trehalose or D-xylose. Can utilize cellobiose (weakly), dulcitol (weakly), D-fructose (weakly), D-glucose, maltose (weakly), D-mannose (weakly), melezitose (weakly), raffinose, D-salicin (weakly), trehalose, glycine and glycogen as sole carbon sources, but not adonitol, L-arabitol, meso-erythritol, L-fucose, inulin, lactose, melibiose, L-rhamnose, D-ribose, sorbitol, sucrose, D-xylose, glycerol, L-asparagine, lactic acid, acetate, formate, pyruvate or succinate. Sensitive to $(10 \mu \mathrm{g}$ per disc) penicillin, ampicillin, kanamycin, neomycin, streptomycin, erythromycin, oxytetracycline, novobiocin and rifampicin. Shows weak sensitivity to lysozyme $(10 \mu \mathrm{g}$ per disc). Major fatty acids ( $>20 \%$ of total fatty acids) are anteiso- $\mathrm{C}_{15: 0}$ and $\mathrm{C}_{18: 0}$. The major menaquinone is MK9. The $\mathrm{G}+\mathrm{C}$ content of the genomic DNA of the type strain is $64.5 \mathrm{~mol} \%$.

The type strain is $\mathrm{LI}^{\mathrm{T}}\left(=\mathrm{DSM} 22826^{\mathrm{T}}=\mathrm{NCCB} 100315^{\mathrm{T}}\right)$, isolated from a moss-covered soil from Livingston Island, South Shetland Islands, Antarctica.

\section{Acknowledgements}

Our special gratitude goes to all colleagues on the Bulgarian base St Kliment Ohridski for supporting fieldwork and logistics, in particular Christo Pimpirev (Bulgarian Antarctic Institute) for leading the expedition Livingston 2005. Furthermore, we wish to thank Hans Hubberten and Georg Schwamborn (Alfred Wegener Institute for Polar and Marine Research) for field assistance. This work was supported by the Deutsche Forschungsgemeinschaft (DFG) in the framework of the priority programme 'Antarctic Research with Comparative Investigations in Arctic Ice Areas' by a grant to D. W. (WA 1554/4)

\section{References}

Bunt, J. S. \& Rovira, A. D. (1955). Microbiological studies of some subantarctic soils. J Soil Sci 6, 119-128.

Chen, M., Xiao, X., Wang, P., Zeng, X. \& Wang, F. (2005). Arthrobacter ardleyensis sp. nov., isolated from Antarctic lake sediment and deepsea sediment. Arch Microbiol 183, 301-305.

Conn, H. J. \& Dimmick, I. (1947). Soil bacteria similar in morphology to Mycobacterium and Corynebacterium. J Bacteriol 54, 291-303.

Ding, L., Hirose, T. \& Yokota, A. (2009). Four novel Arthrobacter species isolated from filtration substrate. Int J Syst Evol Microbiol 59, 856-862.

Dojka, M. A., Hugenholtz, P., Haack, S. K. \& Pace, N. R. (1998). Microbial diversity in a hydrocarbon- and chlorinated-solventcontaminated aquifer undergoing intrinsic bioremediation. Appl Environ Microbiol 64, 3869-3877.

DSMZ (2001). Key to murein (peptidoglycan) types. Braunschweig: DSMZ. http://www.dsmz.de/microorganisms/main.php?content_id=35

Felsenstein, J. (1981). Evolutionary trees from DNA sequences: a maximum likelihood approach. J Mol Evol 17, 368-376.

Felsenstein, J. (1985). Confidence limits on phylogenies: an approach using the bootstrap. Evolution 39, 783-791.

Fitch, W. M. (1971). Toward defining the course of evolution: minimum change for a specific tree topology. Syst Zool 20, 406-416.

Funke, G., Pagano-Niederer, M., Sjödén, B. \& Falsen, E. (1998). Characteristics of Arthrobacter cumminsii, the most frequently encountered Arthrobacter species in human clinical specimens. J Clin Microbiol 36, 1539-1543.

Groth, I., Schumann, P., Weiss, N., Martin, K. \& Rainey, F. A. (1996). Agrococcus jenensis gen. nov., sp. nov., a new genus of actinomycetes with diaminobutyric acid in the cell wall. Int J Syst Bacteriol 46, 234239.

Gupta, P., Reddy, G. S. N., Delille, D. \& Shivaji, S. (2004). Arthrobacter gangotriensis sp. nov. and Arthrobacter kerguelensis sp. nov. from Antarctica. Int J Syst Evol Microbiol 54, 2375-2378.

Hou, X. G., Kawamura, Y., Sultana, F., Shu, S., Hirose, K., Goto, K. \& Ezaki, T. (1998). Description of Arthrobacter creatinolyticus sp. nov., isolated from human urine. Int J Syst Bacteriol 48, 423-429.

Hu, H.-Y., Fujie, K. \& Urano, K. (1999). Development of a novel solid phase extraction method for the analysis of bacterial quinones in activated sludge with a higher reliability. J Biosci Bioeng 87, 378-382.

Hugh, R. \& Leifson, E. (1953). The taxonomic significance of fermentative versus oxidative metabolism of carbohydrates by various gram negative bacteria. J Bacteriol 66, 24-26.

Irlinger, F., Bimet, F., Delettre, J., Lefèvre, M. \& Grimont, P. A. D. (2005). Arthrobacter bergerei sp. nov. and Arthrobacter arilaitensis sp. nov., novel coryneform species isolated from the surfaces of cheeses. Int J Syst Evol Microbiol 55, 457-462. 
Jukes, T. H. \& Cantor, C. R. (1969). Evolution of protein molecules. In Mammalian Protein Metabolism, vol. 3, pp. 21-132. Edited by H. N. Munro. New York: Academic Press.

Kageyama, A., Morisaki, K., Ōmura, S. \& Takahashi, Y. (2008). Arthrobacter oryzae sp. nov. and Arthrobacter humicola sp. nov. Int J Syst Evol Microbiol 58, 53-56.

Kallimanis, A., Kavakiotis, K., Perisynakis, A., Spröer, C., Pukall, R., Drainas, C. \& Koukkou, A. I. (2009). Arthrobacter phenanthrenivorans sp. nov., to accommodate the phenanthrene-degrading bacterium Arthrobacter sp. strain Sphe3. Int J Syst Evol Microbiol 59, 275-279.

Kim, K. K., Lee, K. C., Oh, H. M., Kim, M. J., Eom, M. K. \& Lee, J. S. (2008). Arthrobacter defluvii sp. nov., 4-chlorophenol-degrading bacteria isolated from sewage. Int J Syst Evol Microbiol 58, 1916-1921.

Kodama, Y., Yamamoto, H., Amano, N. \& Amachi, T. (1992). Reclassification of two strains of Arthrobacter oxydans and proposal of Arthrobacter nicotinovorans sp. nov. Int J Syst Bacteriol 42, 234-239.

Kotoučková, L., Schumann, P., Durnová, E., Spröer, C., Sedláček, I., Neča, J., Zdráhal, Z. \& Němec, M. (2004). Arthrobacter nitroguajacolicus sp. nov., a novel 4-nitroguaiacol-degrading actinobacterium. Int J Syst Evol Microbiol 54, 773-777.

Kovács, N. (1956). Identification of Pseudomonas pyocyanea by the oxidase reaction. Nature 178, 703.

Lee, J. S., Lee, K. C., Pyun, Y. R. \& Bae, K. S. (2003). Arthrobacter koreensis sp. nov., a novel alkalitolerant bacterium from soil. Int J Syst Evol Microbiol 53, 1277-1280.

Ludwig, W., Strunk, O., Westram, R., Richter, L., Meier, H., Yadhukumar, Buchner, A., Lai, T., Steppi, S. \& other authors (2004). ARB: a software environment for sequence data. Nucleic Acids Res 32, 1363-1371.

MacKenzie, S. L. (1987). Gas chromatographic analysis of amino acids as the $\mathrm{N}$-heptafluorobutyryl isobutyl esters. J Assoc Off Anal Chem 70, 151-160.

Mages, I. S., Frodl, R., Bernard, K. A. \& Funke, G. (2008). Identities of Arthrobacter spp. and Arthrobacter-like bacteria encountered in human clinical specimens. J Clin Microbiol 46, 2980-2986.

Margesin, R., Schumann, P., Spröer, C. \& Gounot, A.-M. (2004). Arthrobacter psychrophenolicus sp. nov., isolated from an alpine ice cave. Int J Syst Evol Microbiol 54, 2067-2072.

Mesbah, M., Premachandran, U. \& Whitman, W. (1989). Precise measurement of the $\mathrm{G}+\mathrm{C}$ content of deoxyribonucleic acid by high performance liquid chromatography. Int J Syst Bacteriol 39, 159-167.

Minnikin, D. E., O’Donnell, A. G., Goodfellow, M., Alderson, G., Athalye, M., Schaal, A. \& Parlett, J. H. (1984). An integrated procedure for the extraction of bacterial isoprenoid quinones and polar lipids. J Microbiol Methods 2, 233-241.

Phillips, H. C. (1953). Characterization of the soil globiforme bacteria. Iowa State J Sci 27, 240-241.

Pruesse, E., Quast, C., Knittel, K., Fuchs, B. M., Ludwig, W., Peplies, J. \& Glöckner, F. O. (2007). SILVA: a comprehensive online resource for quality checked and aligned ribosomal RNA sequence data compatible with ARB. Nucleic Acids Res 35, 7188-7196.
Ravenschlag, K., Sahm, K., Pernthaler, J. \& Amann, R. (1999). High bacterial diversity in permanently cold marine sediments. Appl Environ Microbiol 65, 3982-3989.

Reddy, G. S. N., Aggarwal, R. K., Matsumoto, G. I. \& Shivaji, S. (2000). Arthrobacter flavus sp. nov., a psychrophilic bacterium isolated from a pond in McMurdo Dry Valley, Antarctica. Int J Syst Evol Microbiol 50, 1553-1561.

Reddy, G. S. N., Prakash, J. S. S., Matsumoto, G. I., Stackebrandt, E. \& Shivaji, S. (2002). Arthrobacter roseus sp. nov., a psychrophilic bacterium isolated from an Antarctic cyanobacterial mat sample. Int J Syst Evol Microbiol 52, 1017-1021.

Roh, S. W., Sung, Y., Nam, Y. D., Chang, H. W., Kim, K. H., Yoon, J. H., Jeon, C. O., Oh, H. M. \& Bae, J. W. (2008). Arthrobacter soli sp. nov., a novel bacterium isolated from wastewater reservoir sediment. J Microbiol 46, 40-44.

Saitou, N. \& Nei, M. (1987). The neighbor-joining method: a new method for reconstructing phylogenetic trees. Mol Biol Evol 4, 406425.

Schleifer, K. H. (1985). Analysis of the chemical composition and primary structure of murein. Methods Microbiol 18, 123-156.

Schleifer, K. H. \& Kandler, O. (1972). Peptidoglycan types of bacterial cell walls and their taxonomic implications. Bacteriol Rev 36, 407-477.

Schröder, H. (1991). Mikrobiologisches Praktikum, 5th edn. Berlin: Volk und Wissen Verlag (in German).

Stackebrandt, E. \& Ebers, J. (2006). Taxonomic parameters revisited: tarnished gold standards. Microbiol Today 33, 152-155.

Süssmuth, R., Eberspächer, J., Haag, R. \& Springer, W. (1999). Mikrobiologisch-Biochemisches Praktikum, 2nd edn. Stuttgart: Georg Thieme (in German).

Tvrzová, L., Schumann, P., Spröer, C., Sedláček, I., Verbarg, S., Kroppenstedt, R. M. \& Páčová, Z. (2005). Polyphasic taxonomic study of strain CCM 2783 resulting in the description of Arthrobacter stackebrandtii sp. nov. Int J Syst Evol Microbiol 55, 805-808.

Wang, F., Gai, Y., Chen, M. \& Xiao, X. (2009). Arthrobacter psychrochitiniphilus sp. nov., a psychrotrophic bacterium isolated from Antarctica. Int J Syst Evol Microbiol 59, 2759-2762.

Wauters, G., Charlier, J., Janssens, M. \& Delmée, M. (2000). Identification of Arthrobacter oxydans, Arthrobacter luteolus sp. nov., and Arthrobacter albus sp. nov., isolated from human clinical specimens. J Clin Microbiol 38, 2412-2415.

Westerberg, K., Elväng, A. M., Stackebrandt, E. \& Jansson, J. K. (2000). Arthrobacter chlorophenolicus sp. nov., a new species capable of degrading high concentrations of 4-chlorophenol. Int J Syst Evol Microbiol 50, 2083-2092.

Zhang, D. C., Schumann, P., Liu, H. C., Xin, Y. H., Zhou, Y. G., Schinner, F. \& Margesin, R. (2010). Arthrobacter alpinus sp. nov., a psychrophilic bacterium isolated from alpine soil. Int J Syst Evol Microbiol 60, 2149-2153.

Zink, K.-G. \& Mangelsdorf, K. (2004). Efficient and rapid method for extraction of intact phospholipids from sediments combined with molecular structure elucidation using LC-ESI-MS-MS analysis. Anal Bioanal Chem 380, 798-812. 